DOI: 10.34015/2523-4552.2020.4.08

УДК 347.965.42

Козакевич О. М.,
аспірантка кафедри
загальнотеоретичної юриспруденції
Національного університету
«Одеська юридична академія»
ORCID: 0000-0002-5528-7008

\title{
РОЛЬ МЕДІАЦІЇ У ЗАБЕЗПЕЧЕННІ ДОСТУПУ ДО ПРАВОСУДДЯ
}

У статті аналізуються теоретичні та практичні аспекти медіації, зокрема, порушується проблема віднесення процедури медіації до елементів доступу до правосуддя. Автором аналізується чинне законодавство та рівень розвитку медіації в Україні. Здійснюється оцінка ролі суду в просуванні медіації при існуючому правовому регулюванні. Також оцінюється можливість призначення процедури медіації за ініціативою суду, проблеми низького рівня застосування медіації, ключові питання, які необхідно вирішити для іï популяризації.

Ключові слова: альтернативне вирішення конфліктів; права людини; право на справедливий суд; доступ до правосуддя; медіація; присудова медіація; безоплатна правова допомога.

В статье анализируются теоретические и практические аспекты медиации, в частности поднимается проблема отнесения процедуры медиации к элементам доступа к правосудию. Автором анализируется действующее законодательство и уровень развития медиации в Украине. Осуществляется оценка роли суда в продвижении медиации при существующем правовом регулировании. Также оценивается возможность назначения процедуры медиации по инициативе суда, проблемы низкого уровня применения медиации, ключевые вопросы, которые необходимо решить для ее популяризации.

Ключевые слова: права человека; альтернативное решение конфликтов; право на справедливый суд; доступность правосудия; медиация; присудебная медиация; бесплатная правовая помощь.

Постановка проблеми. Сучасне українське суспільство, перебуваючи на етапі утвердження фундаментальних правових цінностей та демократії, переживає період глибоких інституціональних та транзитивних змін. У період високої правової невизначеності, недостатньої опрацьованості юридичних нормативів використання альтернативного вирішен- ня спорів у правовій діяльності може не тільки полегшити вирішення юридичних конфліктів, але й забезпечити справедливе рішення та моральне задоволення всіх учасників.

Проведення правових реформ у транзитивних державах спрямоване на захист прав і свободи громадян, забезпечення і розвиток справедливого судового розгляду, тому потре- 
бує нового осмислення правових новацій, які застосовуються у світовій правовій практиці. Сучасною тенденцією $є$ введення конструктивних способів вирішення конфліктів, які дозволяють отримати результат, що максимально задовольняє усіх учасників конфлікту. Головний акцент - це пошук компромісу та вироблення взаємовигідного варіанту вирішення проблеми. Так, у різні історичні епохи існували різноманітні форми врегулювання конфліктів, які передбачали сукупність заходів і рішень, здатних остаточно або принаймні тимчасово погасити конфлікт між сторонами у формі, прийнятній для цього конкретно-історичного суспільства. Інтенсивний розвиток медіації в її сучасному розумінні відбувається в другій половині ХХ ст. у країнах англо-саксонського права США, Австралії, Великій Британії. В країнах континентальної Європі медіація розвивається наприкінці 80-х - початку 90-х років ХХ ст. У 1972 році в США утворена перша професійна організація медіаторів, а у 2004 року в Брюсселі прийнято Європейський кодекс про поведінку медіаторів, який став модельним законом.

Аналіз останніх досліджень та публікацій. Проблематика питань пов'язаних із становленням та застосуванням медіації в Україні стала предметом досліджень таких науковців як Т.Білик, Р.Денисова, В. Землянська, Ю. Рємєскова, Л. Романадзе, Н. Крестовська, Т. Кисельова, Н. Мазаракі, Л. Махова та ін. Предметом наукових дискусій виступають проблеми й перспективи впровадження інституту медіації, загальні питання сутності та змісту медіації, питання законодавчого вре- гулювання правового інституту медіації та його інтеграції у сучасну правову систему України. За наявності великої кількості праць з проблематики медіації, в тому числі - й в загальнотеоретичному аспекті, залишається недостатньо з'ясованою роль медіації у забезпеченні фундаментального права людини - доступі до правосуддя.

Постановка завдання. Метою статті є з'ясування можливостей медіації у забезпеченні доступу до правосуддя, зокрема, вирішення питання щодо розгляду процедури медіації як одного 3 елементів доступу до правосуддя, визначення перспектив впровадження медіації в існуючу систему альтернативних способів вирішення спорів та конфліктів в Україні.

Виклад основного матеріалу. Сучасний етап розвитку суспільних відносин, їх складність і різноманіття потребують удосконалення механізмів захисту прав суб'єктів правовідносин як з точки зору способів захисту прав, так і з точки зору форм і процедур її здійснення. Принцип доступності до правосуддя традиційно у юридичної літературі визначається як забезпечена законом можливість безперешкодно звернутися до суду за захистом своїх прав i отримати правовий захист. Більшість громадян звертаються до суду за захистом вже порушених прав, хоча в багатьох випадках можна i доцільно було би застосувати заходи щодо попередження цих порушень. Традиційні способи вирішення спорів у системі правосуддя, де вирішення спору означає виграш однієї та програш другої сторони, нерідко зумовлюють ескалацію конфлікту та/або припинення відносин його 
учасників. Низка проблем, 3 якими сьогодні стикається судова система, зокрема, перевантаженість суддів, нині зумовили потребу розвитку альтернативних судових процедур врегулювання правових спорів.

Важливою технологію альтернативного вирішення конфліктів $\epsilon$ медіація. Медіація може бути застосована у багатьох сферах життєдіяльності людини, де виникає необхідність контакту з людьми - сім'я, робота, соціум в цілому. Особливо корисною діяльність медіатора може бути для сторін, які перебувають в гострому конфлікті i потребують незалежної третьої сторони, яка допоможе знайти спільні точки дотику у вирішенні конфлікту. Інститут медіації, який отримує сьогодні все більше визнання громадянського суспільства, може використовуватися не лише як самостійна процедура для ефективного вирішення конфлікту, а й як цілеспрямована соціальна програма формування цільового ціннісного простору для відродження і формування соціально-значущих орієнтирів суспільства.

Процедура медіації істотно відрізняється від традиційної судової форми захисту прав громадян, в рамках якої сторони розглядаються як противники; хід процесу визначається процесуальним правом, який, як правило, проходить в умовах гласності судового розгляду. На відміну від судового розгляду вступ обох сторін спору в процес медіації $\epsilon$ добровільним, а медіатор - вільно обраним сторонами, кожна сторона має можливість в будь-який момент вийти 3 процесу. Можна говорити про те, що медіація є найбільш м'якою форму альтернативного засобу доступу до правосуддя.
Аналізуючи становлення медіації в сучасній Україні, Т. Кисельова пише про те, що перші спроби створити підгрунтя для інституціоналізації такої практики в Україні були зроблені в пізні радянські часи. Серед основних передумов авторка називає: розпад Радянського Союзу, хаос у всіх сферах соціального життя, масштабні робітничі страйки у Донецькій області та інші. Намагаючись взяти участь у вирішенні проблем, група психологів з Донецька вийшла на контакт 3 Американською арбітражною асоціацією та Федеральною службою посередництва і примирення США та наприкінці 80х років разом із ними провела низку спільних радянсько-американських семінарів із вирішення конфліктів у Донецькій та Луганській областях. Результатом цієї місії стали: поперше, створення в Україні першого центру медіації у 1994 році та відкриття восьми центрів медіації по всій Україні за підтримки грантів від USAID, фонду «Євразія» та інших донорів. Медіатори одного з найстаріших центрів (Одеська обласна група медіації, створена 1994 року) провели медіацію першої справи, направленої з суду, ще 1997 року; по-друге, 3 метою врегулювання трудових конфліктів 1998 року уряд України за підтримки фінансованого USAID проекту створив нове урядове агентство - Національну службу посередництва і примирення, що була підзвітна лише Президентові України та уповноважена сприяти врегулюванню колективних трудових спорів [10, с. 75-76].

На наш погляд, значною перевагою медіації $є$ те, що така процедура не обмежена жодною галуззю права. Так, Л. Махова пише, що сфера 
застосування медіації не обмежується певним видом конфліктів, її проведення, по суті, можливе майже у будь-яких спорах:

примирення потерпілого та правопорушника при вчиненні злочину невеликої тяжкості;

налагодження стосунків подружжя та встановлення нормальних взаємовідносин поза шлюбом, тобто сімейні спори, спори між членами родини (розлучення, розділ майна, спадщини, визначення місця проживання і питання спілкування 3 дитиною після розлучення та багато інших);

добропорядне сусідство;

примирення роботодавця 3 робітником, тобто трудові спори (звільнення працівника, виробничі конфлікти, конфлікти всередині трудового колективу або між колективами);

вирішення проблем відшкодування моральної та/або матеріальної шкоди;

у галузі корпоративного управління - вирішення конфліктів між членами ради по встановленню меж між наглядом та управлінням, спори акціонерів та інвесторів, між компанією та посадовими особами;

в адміністративних справах це позасудова процедура з вирішення спору між органами державної влади чи місцевого самоврядування та приватними особами, яка спрямована на мирне вирішення публічноправових спорів, налагодження діалогу між громадянами та органами влади, розвантаження адміністративних судів (наприклад, при реалізації інфраструктурних проектів, при вирішенні питань охорони навколишнього середовища та інші); застосування медіації можлива і при вирішенні міжнародних конфліктів.

Наявні приклади ефективного застосування медіації в політичній сфері, у сфері охорони довкілля, громадської ініціативи, в галузі економіки та управління, розміщення промислових підприємств, проектів дорожнього будівництва, утилізації відходів тощо. 3 вище викладеного зрозуміло, що застосування медіації не обмежується лише переліченими сегментами правового поля [8, с. 204].

Зауважимо, що застосування медіації ефективно при вирішенні спорів в системі надання медичних послуг, страхових послуг, кредитних послуг, туристичних послуг, конфліктів в освітній сфері (між учителями і дітьми, батьками та педагогічним складом, між однолітками) та іншими.

У наукових дослідженнях подаються різні підходи щодо класифікації моделей медіації. Для нашого дослідження важливим є поділ медіації залежно від способу взаємодії процедури медіації саме із судовим провадженням, дослідники розрізняють:

позасудову медіацію, тобто приватну медіацію в спорі, що не переданий на розгляд суду, яка $\epsilon$ самостійним способом альтернативного вирішення спорів, існує паралельно із судовим провадженням та проводиться незалежними приватними медіаторами;

присудову медіацію, тобто медіацію, яка проводиться ніби при суді, $\epsilon$ інтегрованою в судове провадження, використовується для вирішення спорів, що, як правило, уже стали предметом судового розгляду, за згодою сторін або за призначен- 
ням чи рекомендацією судді. Присудова медіація, у свою чергу, також може бути поділена на декілька різновидів [10, с. 122-126].

Дисертаційне дослідження Н. Грень присвячено саме аналізу теоретико-правових аспектів реалізації права людини на справедливий суд через процедуру присудової медіації. Дослідниця вважає, що присудова медіація $є$ самостійним видом медіації, який інтегрований в судову систему країни, в якому сторони мають право на будь-якій стадії судового розгляду перервати процес і звернутися до процедури медіації, а на суд покладається обов'язок запропонувати сторонам використовувати їі в разі медіабельності спору, в подальшому затвердити результати як встановлення юридично значущого акту двосторонньої поведінки, що має обов'язкову силу для них. Крім того, авторка доводить, що саме присудова медіація $\epsilon$ однією з ефективних процедур, яку необхідно налагодити у світлі забезпечення права людини на справедливий суд та яка може стати одним з основних принципів зміни політики судової влади у світлі євроінтеграційних процесів [2, c. 192].

Стаття 20 законопроекту № 3504 від 19.05.2020 р. «Про медіацію» містить положення про те, що суд, третейській суд, міжнародний комерційний арбітраж роз'яснює сторонам у справі їх право на будьякій стадії судового, третейського, арбітражного провадження провести позасудове врегулювання конфлікту (спору) шляхом медіації [13]. Отже, судова медіація поєднує соціальне і правове регулювання, в залежності від того, коли вона проводиться - на початку судового розгляду чи у ході нього.

На думку Ц. Шамлікашвілі, сьогодні можна з впевненістю говорити про те, що медіація та судова процедура не лише уживаються разом, але і органічно доповнюють одна одну, дозволяючи громадянам, які звернулися за захистом своїх прав та інтересів, обрати такий спосіб урегулювання конфлікту, який буде для них найефективнішим. Більш того, ці інститути потребують один одного. Медіації сильна, незалежна судова система необхідна як гарант права i, разом із тим, як один із ключових партнерів у розподілі застосування медіації громадянами, як помічник при формуванні культури мирного, не змагального вирішення спорів. Досвід інтеграції медіації в різних юрисдикціях підтверджує ключову роль суддівського співтовариства в успіху процесу впровадження медіації як інституту, затребуваного суспільством [15, с. 121].

Можна констатувати, що концепція інтеграції медіації в судову систему останнім часом все більше набуває актуальності. Завдання інтеграції медіації в судову систему полягає в тому, щоб надати громадянам можливість вибору найбільш доцільного механізму врегулювання конкретного спору із широкого кола різноманітних механізмів. Це мотивуватиме громадян та сприятиме підвищенню особистої відповідальності за вирішення їх спорів. Коли до медіації починають ставитися лише як до інструменту, що дозволяє позбутися судових справ (своєрідна «катапульта»), їі сутність стає викривленою [5, с. 22]. Серед авторів зазначеної концепції Ц. Шамлікашвілі, яка називає наступні причини необхід- 
ності комплексної інтеграції медіації в роботу судів, інститут медіації сприяє: захисту прав та інтересів громадян, пропонуючи спрощену i прискорену процедуру; розвантаженню судової системи і системи примусового виконання судових рішень; підвищенню рівня правової культури, розвитку партнерських ділових відносин і формуванню етики ділового обороту, гармонізації соціальних відносин і зниження конфліктності в суспільстві; врахувати ті важливі для сторін аспекти спору, які в силу об'єктивних причин не можуть бути розглянуті судом [9, c. 11-13].

Впровадження інституту медіації в Україні змістовно пов'язує сучасний розвиток правової системи України 3 європейськими правовими системами, цінностями та пріоритетами розвитку сучасного цивілізованого світу. Становлення та розвиток медіації в Україні протягом останніх десятиліть дає підстави стверджувати, що такий метод вирішення спорів набув статусу соціального інституту. Мирне вирішення конфлікту - ознака притаманна українській ментальності, а стан вітчизняної судової системи спонукає громадян шукати та застосовувати альтернативні процедури вирішення спорів. Більше того, йдеться про наявність стійкого соціального запиту на реформування судової гілки влади, покращення доступу до правосуддя, зниження рівня конфліктності у суспільстві. За таких умов інститут медіації розглядається як один з органічних доповнень державної судової системи.

Попри відсутність спеціального законодавства, медіація презентується як найпростіша, найпоширені- ша у світі, найдоступніша для людей, найдешевша, зважаючи на обмежені ресурси сучасного українського суспільства, альтернатива офіційного судочинства; як процес досудового врегулювання спорів, що містить багато переваг, на відміну від довготривалого судового розгляду.

За даними Міністерства юстиції України, починаючи з 2003 року в судовій системі, на експериментальних засадах, активно впроваджується застосування медіаційних процедур. Значна роль в цьому процесі належить громадським організаціям, зокрема, регіональним групам медіації, діяльність яких, в першу чергу, спрямована на популяризацію медіації, впровадження програм примирення та діалогу. Відсутність державних інституцій, нормативного забезпечення, інформаційної підтримки та чіткого механізму реалізації $\epsilon$ свідчення того, що на даному етапі медіація в Україні функціонує переважно на громадських засадах. Слід підкреслити, що активна співпраця юридичної спільноти, включаючи суддів, з діючими центрами медіації сприятиме подальшому розвитку інституту медіації.

В Україні медіація існує вже більше 20 років, з кожним роком зростає кількість фахівців, які застосовують на практиці техніки медіації, а процес проведення медіації $є$ добровільним і залежить тільки від волі сторін. Разом з тим відкритим залишається питання прийняття спеціалізованого законодавства у сфері медіації. За ініціативи фундаторів української медіації та за підтримки парламентарів у Верховній Раді України $з 2010$ року зареєстровано десять законопроектів про медіацію. Однак через нестабільну політичну 
ситуацію, постійні зміни урядів і парламентські вибори закон досі не прийнято [3, с. 6]. Так, 28 лютого 2019 року Верховна Рада України відхилила законопроект №3665 «Про медіацію», який розглядався у другому читанні. Законопроект передбачав формування правових засад та порядку проведення медіації як позасудової процедури врегулювання конфлікту, принципи медіації, статус медіатора. Визначалося, що медіація може застосовуватися у будь-яких конфліктах, у тому числі цивільних, сімейних, трудових, господарських, адміністративних, а також у провадженні щодо кримінальних проступків, злочинів невеликої чи середньої тяжкості та у кримінальному провадженні у формі приватного обвинувачення, передбаченого ст. 477 КПК України, та справах про адміністративні правопорушення [12]. Інший законопроект «Про діяльність у сфері медіації» №10425, був знятий 3 розгляду у зв'язку з розпуском Верховної Ради [11].

15 липня 2020 року Верховна Рада України прийняла за основу поданий Кабінетом Міністрів України проект Закону України «Про медіацію» (№ 3504), який на законодавчому рівні закріплює можливість проведення процедури медіації. Комітету Верховної Ради України з питань правової політики доручено доопрацювати зазначений законопроект $з$ урахуванням зауважень i пропозицій суб'єктів права законодавчої ініціативи [13]. Таким чином, відзначається висока активність суб'єктів законодавчої ініціативи, спрямована на врегулювання в Україні медіації. Але багаторічні спроби прийняти якісний закон не увінчалися успіхом.
За умов відсутності спеціального закону певні можливості для впровадження медіації в юридичну практику та практику надання правничої допомоги в Україні надає галузеве законодавство. Можна говорите про те, що завдяки судовій реформі 2017 року на законодавчому рівні встановлені певні нормативи здійснення практики медіації. Відповідно до п. 2 ч. 1 ст. 70 Цивільного процесуального кодексу України, п. 2 ч. 1 ст. 67 Господарського процесуального кодексу України, п. 2 ч. 1 ст. 66 Кодексу адміністративного судочинства України передбачено, що не можуть бути допитані як свідки особи, які за законом зобов'язані зберігати в таємниці відомості, що були довірені їм у зв'язку з наданням професійної правничої допомоги або послуг посередництва (медіації) під час проведення позасудового врегулювання спору [1; 6; 16]. У п. 8 ч. 2 ст. 65 Кримінального процесуального кодексу України також закріплено, що особи, які брали участь в укладенні та виконанні угоди про примирення в кримінальному провадженні, не можуть бути допитані в якості свідків щодо обставин, які стали їм відомі у зв'язку 3 участю в укладенні та виконанні угоди про примирення [7]. У зазначених правових приписах йдеться про конфіденційність інформації, яку сторони довіряють незалежному посереднику в ході проведення медіації.

Крім того, ч. 6 ст. 16 Закону України «Про соціальні послуги» медіація визнається базовою соціальною послугою, а ч. 2 ст. 7 Закону України «Про безоплатну правову допомогу» закріплюється, що безоплатна первинна правова допомога 
включає такий вид правової послуги, як надання допомоги в забезпеченні доступу особи до медіації [14].

У серпні 2019 року Україна підписала в Сінгапурі Конвенцію ООН щодо медіації, яка спрямована на те, аби в майбутньому транскордонні комерційні спори частіше вирішували за допомогою посередництва (медіації) та шляхом укладання мирових угод [18]. Підписання Сінгапурської Конвенції Україною підвищує авторитет та довіру до процесу медіації, як альтернативного засобу врегулювання спорів та позитивно впливає на імідж країни на міжнародній арені, а також на розвиток міжнародної торгівлі та бізнесу в Україні.

Важливо відмітити ще один аспект необхідності розгляду медіації в контексті доступу до правосуддя. Євроінтеграційний вектор правової політики України, що передбачає апроксимацію національного законодавства до права ЄС, зумовлює звернення до позицій, які визначають роль медіації у системі правосуддя як ЄC, так і його членів. Директива Європейського Парламенту та Ради ЄС «Про певні аспекти медіації у цивільних та комерційних справах» від 21 травня 2008 року прямо зазначає, що альтернативні позасудові процедури своєю метою мають забезпечення кращого доступу до правосуддя «Забезпечення кращого доступу до правосуддя, яке становить частину політики Європейського Союзу, спрямованої на встановлення простору свободи, безпеки та правосуддя, має включати доступ як до судових, так і позасудових методів врегулювання спорів» [4].

Однак, сучасні дослідники констатують, що як новий невластивий для України правовий інститут меді- ація поки не набула поширення в нашому суспільстві. Так, аналізуючи проблеми впровадження та проведення медіації в Україні, I. Ясиновський зазначає, що в Україні впровадження медіації здійснюється надто повільними темпами, в порівнянні із іншими державами, зокрема Росією, Білоруссю, Грузією. Цьому, на думку автора, заважає низка причин: низький рівень правової культури населення; низький рівень довіри до медіативної послуги; недостатня поінформованість громадян про медіацію, i переваги як альтернативного судовому розгляду; позиції сторін, які не бажають іти на компроміс; специфіку національного правосуддя; низький рівень співпраці з міжнародними організаціями; відсутність належної фінансової підтримки; громадські засади розвитку медіації; складність вибору медіатора як високопрофесійної особи; відсутність спеціалізованого законодавства [17, с. 261-264].

Підтримуємо існуючі у правовій літературі точки зору, що медіація $€$ органічним доповненням судової системи i покликана сприяти вдосконаленню суспільних відносин, підвищення довіри суспільства до інституту права. Тому, на наш погляд, дуже важливим завданням $\epsilon$ просвітницька діяльність, спрямована на широке інформування сторін конфлікту про можливості медіації та їі переваги. Важливу роль щодо такого інформування громадян належить і суддям. Так, для суддів, їх помічників, працівників апарату суду важливим є знання основ медіації та володіння медіативними навичками, завдяки яким можливо професійне спрямування сторін на процедуру медіації. 
Застосування медіації для вирішення спору забезпечує різноманіття засобів захисту прав громадян без обмеження права на судовий розгляд, що сприяє підвищенню довіри до суду і в цілому до інститутів держави. Можливість вибору медіації для громадянина, поряд з судовим способом захисту прав, дозволяє учасникам усвідомлено обирати спосіб захисту своїх права, в залежності від конкретних обставин справи.

Висновки. В умовах сучасного транзитивного суспільства, що характеризується значним динамізмом i нестабільністю правової регламентації відносин, які потребують ефективного врегулювання, слід визнати обгрунтованість підходу, який визнає за мирним врегулюванням спору статус першорядної мети судочинства. Узагальнюючі існуючі дефініції, зауважимо, що медіація, це технологія альтернативного регулювання спорів (англ. alternative dispute resolution, ADR) за участю третьої нейтральної, неупередженої, не зацікавленої в даному конфлікті сторони - медіатора, який допомагає сторонам виробити угоду щодо конфлікту, при цьому сторони повністю контролюють процес прийняття рішення 3 врегулювання конфлікту і умови його вирішення.

Підкреслимо, що присудова медіація, це потрібний інститут для законодавства України, який має певні переваги перед традиційним судочинством та сприяє впровадженню справедливого, зручного, швидкого способу вирішення спорів, сприяє доступу до правосуддя та підвищенню рівня довіри до судової системи. Становлення інституту присудової медіації є закономірним результатом розвитку процесуального законодавства та запровадження процедури медіації в правовій системі України.

\section{Список використаних джерел}

1. Господарський процесуальний кодекс України: Закон України від 6 листопада 1991 р. № 1798-XII URL: https://zakon.rada.gov.ua/laws/show/179812\#Техt (дата звернення: 01.12.2020).

2. Грень Н. М. Реалізація права людини на справедливий суд шляхом процедури присудової медіації: теоретико-правове дослідження: дис. ... канд. юрид. наук. Львів, 2016. 250 с.

3. Денисова Р. О. Інститут медіації в Україні (національно-історичний аспект). Теорія і практика правознавства. 2018. Вип. 1 (13). С. 1-9.

4. Директива Європейського Парламенту та Ради ЄС «Про певні аспекти медіації у цивільних та комерційних справах» від 21 травня 2008 p. URL: https://zakon.rada.gov.ua/laws/show/994_a95 (дата звернення: 01.12.2020).

5. Кисельова Т. Інтеграція медіації в судову систему України: програмний документ. Київ, 2017. 28 с.

6. Кодекс адміністративного судочинства України: Закон України від 6 липня 2005 p. № 2747-IV URL: https://zakon.rada.gov.ua/laws/show/2747-15\#Tеxt (дата звернення: 01.12.2020).

7. Кримінальний процесуальний кодекс України: Закон України від 13 квітня 2012 p. № 4651-VI URL: https://zakon.rada.gov.ua/laws/show/4651-17\#Text (дата звернення: 01.12.2020). 
8. Махова Л. О. Межі застосування медіації в України. Матеріали Всеукр. наукпракт. круглого столу «Актуальні проблеми конвергенції екологічного законодавства Украӥни до законодавства Європейського Союзу». Дніпро, 2016. С. 203-206.

9. Медиация в судебной системе: Сборник материалов /Составитель Ц.А. Шамликашвили. Москва : Издательство 000 «Межрегиональный центр управленческого и политического консультирования», 2017. 182 с.

10. Медіація у професійній діяльності юриста : підручник / авт. кол.: Т. Білик, Р. Гаврилюк, І. Городиський [та ін.] ; за ред. Н. Крестовської, Л. Романадзе. Одеса : Екологія, 2019. 456 с.

11. Про діяльність в сфері медіації: проект Закону України від 05.07.2019 p. № 10425 URL: https://w1.c1.rada.gov.ua/pls/zweb2/webproc4_1?pf3511=6 6139 (дата звернення: 01.12.2020).

12. Про медіацію: проект Закону України від 17.12.2015 р. № 3665 URL: http://w1.c1.rada.gov.ua/pls/zweb2/webproc4_1?pf3511=57463 (дата звернення: 01.12.2020).

13. Про медіацію: проект Закону України від 19.05 .2020 р. № 3504 URL: http://w1.c1.rada.gov.ua/pls/zweb2/webproc4_1?pf3511=68877 (дата звернення: 01.12.2020).

14. Про соціальні послуги: Закон України від 17.01.2019 р. № 2671-VIII (введення в дію 01.01.2020). URL: https://zakon.rada.gov.ua/laws/show/2671-19 (дата звернення: 01.12.2020).

15. Суд. АРС. Медиация : сборник статей. Составитель Ц. А. Шамликашвили. Москва : Издательство 000 «Межрегиональный центр управленческого и политического консультирования», 2017. 140 с.

16. Цивільний процесуальний кодекс України: Закон України від 18 березня 2004 p. URL: https://zakon.rada.gov.ua/laws/show/1618-15\#Text (дата звернення: 01.12.2020).

17. Ясиновський І. Г. Проблеми впровадження та проведення медіації в Україні. Актуальні проблеми політики. 2015. Вип. 55. С. 260-267.

18. Sussman E. (2018) The Singapore Convention. Promoting the Enforcement and Recognition of International Mediated Settlement Agreements. ICC Dispute. URL: https://sussmanadr.com/wp-content/uploads/2018/12/ICC-Singapore-ConventionSussman-10-2018-2.pdf (дата звернення: 01.12.2020).

\section{References}

Gren, N. M. (2016). Realizatsiia prava liudyny na spravedlyvyi sud shliakhom protsedury prysudovoi mediatsii: teoretyko-pravove doslidzhennia (Dys. ... kand. yuryd. nauk). Lviv [in Ukrainian].

Denysova, R. O. (2018). Instytut mediatsii v Ukraini (natsionalno-istorychnyi aspekt). Teoriia i praktyka pravoznavstva, 1 (13), 1-9 [in Ukrainian].

Kyselova, T. (2017). Intehratsiia mediatsii v sudovu systemu Ukrainy: prohramnyi dokument. Kyiv [in Ukrainian].

Makhova, L. O. (2016). Mezhi zastosuvannia mediatsii v Ukrainy. Materialy Vseukr. nauk-prakt. kruhloho stolu «Aktualni problemy konverhentsii ekolohichnoho zakonodavstva Ukrainy do zakonodavstva Yevropeiskoho Soiuzu». Dnipro, 203-206 [in Ukrainian].

Sud. ARS. Medyatsyia : Sbornyk statei /Sostavytel Ts.A. Shamlykashvyly. Yzdatelstvo 000 «Mezhrehyonalnы tsentr upravlencheskoho y polytycheskoho konsultyrovanyia» (2017). [in Russian].

Krestovska, N. (2019). Mediatsiia u profesiinii diialnosti yurysta. Odesa: Ekolohiia [in Ukrainian]. 
Yasynovskyi, I. (2015). Problemy vprovadzhennia ta provedennia mediatsii v Ukraini. Aktualni problemy polityky, 55, 260-267 [in Ukrainian].

O. Kozakevych, Postgraduate student, Department of General Theoretical Jurisprudence, National University "Odessa Law Academy"

ORCID: 0000-0002-5528-7008

\section{The role of mediation in ensuring access to justice}

The article analyses theoretical and practical aspects of the mediation in Ukraine and raises the problem of attributing mediation procedure to the elements of access to justice. The author analyses current national legislation, development level of mediation in Ukraine, assesses the role of court and judges in promoting mediation under the current legal framework.

The article considers the issue of emerging, formation and development of mediation as a new social institution and national statutory institution in the contemporary transitional period. The author outlines the range of legal disputes that may be resolved through mediation, these are: labour, family, economic, corporate disputes, international conflicts. Eventually mediation may be applied to various conflicts in the fields of medical, insurance, credit, travel services, education etc. Attention is drawn to the benefits of mediation for the development of partnerships and harmonization of social relations. Advantages of mediation comparing traditional justice are the following: fair, convenient, cost-effective, fast way of dispute resolution.

Specific attention is given to the opportunity of court-related mediation, and to the reasons for the infrequent use of mediation in Ukraine, and key issues of its popularization and promotion. The article focuses on the concept of integration of mediation into Ukrainian judiciary. In particular, the analysis of current legislation indicates the need for legislative regulation of the mediation. Concludes that mediation promotes access to justice and increases social trust in justice.

Keywords: alternative conflict resolution; human rights; the right to a fair trial; legal procedure; access to justice; mediation; court-related mediation; free legal aid.

(C) Козакевич О. М., 2020 